\title{
Psychological Biases, Main Factors of Financial Behaviour - A Literature Review
}

\author{
MSc. Blerina Dervishaj \\ Department of Finance, University of Vlora "Ismail Qemali" “Pavarësia" Square, \\ Vlora, Albania
}

\section{Abstract}

In the context of the sophistication of financial relationships, investment alternatives, risk and recurrent recent financial crises, human factor has become increasingly important in investor decision-making. Studies on investment behavior of a number of authors at different times and places, encouraged this new widely accepted inter-disciplinary field of finance: Behavioral Finance. In order to understand and explain individual decision making and investment behavior, it is necessary to study behavioral factors which impact it. Various scholars have studied factors of financial behavior and their impact on financial decision making, and in particular a special focus has been given to psychological biases. Usually investors are not aware of their behavioral biases. If investors become conscious of biases they can face, they can act more rationally. This way of thinking might increase the quality of their decision-making. The paper aims to help decision-makers and investors get to know with psychological biases, in order to make better decisions when investing, reducing the chances of being vulnerable to behavioral deviations, as the consequences of individual errors are inevitably reflected at a macro level, causing instability and economic - financial crisis.

Keywords: financial behavior, investor, psychological biases, decision - making.

\section{Introduction}

"The investor's chief problem - and even his worst enemy - is indeed to be himself."

Benjamin Graham, and a well-known investor, economist professor in USA.

Studies of several authors at different times and places on investment behavior have created a new field of finance that has been widely accepted: Behavioral Finance. This new way of analyzing an increasingly important factor of investment decisionmaking, basically examines why people do not make the decisions they need to take and why markets don't react the way they are expected and should react. Behavioral Finance is based on the assumption that the information structure and characteristics 
of market participants systematically effect individual investment decisions as well as the performance of financial markets.

In order to understand and explain individual investment behavior and decision making, it is necessary to study behavioral factors which affect it. Researchers have studied financial behavior factors and their influence on financial decision making, such as psychological biases, socio-demographic factors, investor personality type, risk-taking, culture, etc.(Durand, Newby and Sanghani 2008; Venter, Michayluk 2007, Grabova 2013).Among the above - mentioned factors, we highlight the psychological biases on which the academics of Behavioral Finance, have done a colossal work to verify their existence. Two well-known israeli psychologists, Kahneman and Tversky have played a very important role in developing theories and discovering psychological biases in the field and a great number of other researchers have contributed to their theoretical and empirical findings.

In many cases, investors are not aware of biases in their behaviors. If investors are aware of the psychological bias they face, they can make financial decisions in a more rational manner. Thus, it would increase the quality of their decisions. If an investor knows himself better, he can earn more or preserve his property (Zweig, 2011). The paper aims to introduce investors to the psychological biases so that they can make more logical decisions when investing, reducing their chances to 'fall for it', because the consequences of the mistakes of these micro-actors are inevitably reflected at the macro level, causing instability and the economic-financial crisis.

The paper is organized as below: First, we are introduced with the psychological biases and their classification based on literature, then we list other psychological biases out of this classification, but not less important and finally we present a theoretical summary of the studies on psychological biases, executed by various scholars in the field of financial behavior.

\section{Psychological Biases}

Investors' way of thinking and feeling affects their behavior when making investment decisions. These impacts are known as psychological or behavioral biases. They affect all investors and vary depending on the investor's nature. According to Pompian (2011), they can be cognitive or emotional. Cognitive bias include: overconfidence, representativeness, anchoring, framing, cognitive conflict, availability, mental accounting etc. Emotional prejudices include: loss aversion, optimism and status quo bias.

Shefrin (2000) classifies psychological biases in biases based on Heuristic theory and biases based on Framing theory. Heuristic biases include: overconfidence, excessive optimism, representativeness, anchoring, and availability. Framing biases include: loss aversion, mental accounting, disposition effect, etc. Kahneman and Tversky were the first researchers to study the biases involved in heuristic factors such as representability, anchoring, and availability (Kahneman \& Tversky, 1974). Waweru 
et al. (2008), add two other biases to this factor: gambler's fallacy and overconfidence. The same authors classify into Perspective Theory the following biases: loss aversion, regret aversion, and mental accounting. They study the Herding bias as a specific factor of financial behavior, because of the importance it has.

Investors should be aware of presence of these deviations. Most of them being a natural part of human behavior, they can negatively affect the ability to improve the financial position. Accordingto the above classification (Waweru et al., 2008), we present psychological biases categorized by: Heuristics, Perspective Theory and Herding.

\section{Biases based on Heuristics}

\section{Representativeness}

Representativeness is stereotyped decision-making as a "representative" of all members of a group. The bias is manifested when we judge the probability that $A$ belongs to class $B$, seeing the degree to which $A$ resembles $B$. When we do this, we neglect the information about the general probability that B will occur, its base rate (Kahneman \& Tversky, 1972). Let's refer to the example below: Problem 6: Ben likes the opera, and in his spare time, he likes to visit art museums. When he was a kid, he enjoyed playing chess with family members and friends. What do you think is Ben's profession as an adult?
A. Ben plays in a symphonic orchestra.
B. Ben is a merchant.

Many people will choose A, because Ben's description matches the stereotype we can relate as a classical musician instead of the merchant. In reality, the probability that $B$ is true is much higher because merchants make up a larger percentage of the population.

Assessments based on similarity are generally a short-term cognitive approach commonly used in all areas of life. For example, a customer can attribute a relatively high quality to a product if its packaging is designed to resemble a famous brand (Kardes, Posavac, \& Cronley, 2004).

In investment, representativeness is a bias to be more optimistic about the recent well- performing investments and more pessimistic for past bad-performed investments. Thus investors prefer to buy stocks that have had recent abnormal high returns as an indicator of a good investment (Chen et al., 2007). The bias presents when investors label an investment as good or bad based on its recent performance. Consequently, they buy stocks after prices have risen, expecting these growth continuation and ignore stock purchases when their prices are below their basic values (Baker and Ricciardi,2014). 


\section{Availability Bias}

This bias is defined as the preference of decision-makers for the easily called to memory information or events. Bias of availability refers to the human bias to judge the probability of an event to occur or its frequency, from the facility it can be recalled. This happens when we overrate the probability of something happening either because a similar event has happened recently, or because we feel very emotional about a previous similar event.

Due to availability biases, our perception of risk may be wrong, it distorts real risk understanding, which can have fatal impacts. Easy recalling suggests that if something is easier to remember, then there is a higher probability that it will happen. When we make decisions, we tend to get impacted from what we remember. What we remember, is influenced by various elements like beliefs, expectations, emotions and feelings, as well as frequency of exposure. Media (internet, radio, television) also affects our memory. Rare events are very noticeable to us when they occur, because they get a great coverage from the media, increasing the probability to remember them, especially after the event has happened. But remembering an event and its assessing its probability are two different things. For example, if you have a car accident, you are more likely to estimate the chances of having another car accident far higher than the real probability. A study by Karlsson, Loewenstein and Ariely (2008), showed that people are more likely to buy insurance to protect themselves after a natural disaster they have just experienced than to buy insurance before the disaster happens. Another example is that in the case of an aircrash, the airline company's stocks suffer a drastic fall of their prices until the first week after the disaster strikes. When the event starts to be forgotten, stock prices begin to rise again (Kahneman, 2011).

\section{Anchoring}

Anchoring occurs when an individual allows specific information to control his cognitive decision-making process. When people want to estimate an unknown quantity, they refer to a certain value and the evaluation they make is close to the value they are referring to (which serves as an "anchor"). If you need to think about how much you have to pay to buy a home, you will be influenced by the seller'sprice. Any number you are required to consider as a possible solution to a problem that requires assessment, will be influenced by the anchoring phenomena. Anchoring effects are easily applied in auctions, where the initial offer has a powerful impact. In the investment context, one consequence is that market participants exhibiting the anchor bias, tend to hold investments with a reduced value because they "anchor" their fair value estimation at the initial purchase price, rather than their internal value.

As a result, market participants get higher risk by keeping the investment hoping that the asset price will rise again up to the purchase price level. Anchoring may be the reason an investor refuses a proper decision (to buy an undervalued asset / to sell an 
overvalued asset), or to accept a wrong decision (ignore an undervalued asset or buy or hold an overestimated asset). Historical values like purchase prices usually serve as "anchors", which we refer to achieving certain objectives as a specific level of return or net income.

Anchoring Index - Anchoring Deviation can be measured by an indicator called the Anchoring Index which is clearly illustrated in the following example ${ }^{1}$. Answer the questions below, addressing them separately from each other:

Was Gandhi more than 114 when he died? How old do you think it was when he died?

Was Gandhi more than 35 years old when he died? How old do you think it was when he died?

The answer you would give to the second question would differ from the answer to the first question, as it would be respectively a smaller number than it, best showing the anchoring effect. Both questions above served as an experiment to measure the anchoring index and from the calculations it turns out that the average of the first answer was 95 years old, and the second answer was 52 years old. The anchoring index expresses the ratio of the difference between the averages of the answers given with the difference of the "anchors" given and expressed in percentage. Specifically: (95-52) / (114-35) $=54.4 \%$, meaning that the anchoring effect has been significant. This index is $100 \%$ for people who use the value "anchor" to estimate and $0 \%$ for people who ignore "anchor".

Inreal estate context, Northcraft and Neale (1987) studyanchoringwithin a group of students and real estate agents. These researchers require that entities make decisions about prices related to real estate properties. In accordance with the studies of Slovic P \& Lichtensteln, (1971) and Tversky and Kahneman (1974) on the Anchor bias, Northcraft and Neale predict that an "anchor" random selection will affect real estate pricing value. In their experiment, they discover that the initial required price of a house served as an "anchor" in the acquisition process, where all other information about the property and its location remained the same.

In investment, investors often base their decisions on the first source of information to which they are exposed (e.g. an initial purchase price of an asset) and have difficulties adjusting their viewpoint towards the new information. To avoid anchoring, investors need to consider a wide range of investment alternatives and not focus their financial decisions on a specific reference point of information (Ricciardi, 2012).

\section{Gambler's fallacy}

The inability to understand probability can lead to false assumptions and predictions regarding the occurrence of events. According to this bias, an individual believes by

\footnotetext{
1 "Thinking fast and slow", Kahneman 2013
} 
mistake that the occurrence of a certain random event is less likely to occur after a series of events occurs. This way of thinking is not, right, because past events do not change the possibility for certain events to occur in the future. For example, if we toss a coin 20 times and it flips 'heads', anyone can predict that the next time is more likely to flip 'tails'. This way of thinking represents an incorrect meaning of probability because the possibilities that a coin lands "heads" are always $1 / 2$. Each toss is an independent event, which means that the previous do not impact the next ones.

We can find other examples such as people and their relationship with slot machines. There are people who "block themselves" in a single machine for hours. Most of these people believe that any single losswill bring them closer to winning. They do not realize that due to the way the machines are programmed, the chances of winning a first prize from a slot machine is equal to any withdrawal, so it does not make any difference if you play with a slot machine in which you just won, or with another one which hasn't made a winner recently.

Under certain circumstances, investors may easily fall for this bias. For example, some investors believe they have to close a position (sell one share), as the stock is overtraded and highly estimated for a long period of time, and they do not think that this position will continue to improve (the price will rise). On the other hand, other investors may continue to hold shares that have dropped in value several times because they seea further drop in price as "impossible".

When the events are independent, the odds for any future specific result remain the same regardless of the previous result. Selling a share just because of your belief that prolonged bias is likely to change at any moment is irrational.

\section{Overconfidence Bias}

Overconfidence is a psychological bias in which people overestimate their accuracy or the probability that a certain outcome will occur (Campbell, Goodie and Foster 2004; Glaser and Weber 2010). People tend to have excessive self-esteem for their skills and knowledge to carry out a particular task successfully. There is a genuine bias in which a person's subjective belief in his judgments is greater than the objective accuracy of those judgments. Overconfidence is defined in three forms: (1) overestimating current performance; (2) Overlapping the person's performance compared to others; (3) Overestimate the accuracy of the information he possesses.

This bias affects the financial decisions of investors and managers. Managers' overconfidence can explain the high rate of failure of newly-established businesses (Camerer and Lovallo, 1999). In a survey ${ }^{1}$ of 300 professional fund managers, resulted that $74 \%$ of them believed that they had a performance above average, while $26 \%$ considered themselves average, so almost $100 \%$ of respondents believed that their

\footnotetext{
1 "Behaving Badly", James Montier, 2006
} 
work performance was average or above average. It is considered as the most widespread psychological bias victim of which human beings are.

The most common way in which high self-esteem is studied is by asking people how confident they are for their answers. The data collected, shows that overconfidence systematically surpasses accuracy, implying that people are more confident than accurate. If human self-confidence had a perfect calibration, $100 \%$ confident judgments would be $100 \%$ correct, with $90 \%$ confident judgments would be $90 \%$ accurate, and so on for other levels of confidence ${ }^{1}$. There is a thin line between confidence and overconfidence. Confidence implies realistic faith in one's own abilities, while overconfidence usually implies an overly optimistic reliability of the knowledge or control of a situation.

There is a positive connection of overconfidence and the level of trading volume on the stock exchange (Grinblatt and Keloharju, 2001), (Odean, 1998). Overconfident investorstend to believe that they are more capable than others in stock selection and finding the best moment to enter or leave a position while those who overtrade, usually have aweaker performance compared to that of the markets (Barber and Odean 2000, 20012), (Ricciardi 2008).

Individual investors are less likely to have better information, intuition or analytical skills than others.In reality, the market has "fooled" many sophisticated professionals with high self-esteem.

According to an experimental study, less informed investors have more confidence than their more informed counterparts (Bloomfield, Libby and Nelson, 1999). In real estate markets, an inexperienced individual who has recently sold his property with a gain is likely to exhibit a high level of self-confidence when seeking to purchase a future real estate. As a result, he is likely to pay a higher amount of money to buy it or reject a potentially appealing investment opportunity. Wang (2000) studies the builders' self-confidence in the real estate market and notice that overconfidence relates to excessive building in markets where prices rise quickly.

\section{Bias based on the Theory of Perspective}

It describes a mental condition that affects the individual decision-making processes, including Regret Aversion, Loss Aversion, and Mental Accounting (Waweru et al., 2008, p. 28).

\footnotetext{
${ }^{1}$ Investor Behaviour, Baker and Ricciardi 2014

${ }^{2}$ Barber and Odean (2001) study trading behavior and gender differences for a sample of 35,000 individuals over six-year period. Their findings show that men trade more often than women. Compared to women, men tend to sell stocks at an inappropriate time with higher trading costs. Women generally trade less and have lower trading costs.
} 


\section{Regret Aversion}

Regret is a sense of responsibility for loss or disappointment. Past decisions and their outcomes inform your current decisions, but regret may divert your decision-making. Regret can strongly anchor you in your past experience and prevent you from seeing new opportunities. People anticipate to suffer the feeling of "regret" if they make a wrong choice and take this prediction into consideration when making decisions. The fear of feeling repentance can play a major role in preventing or motivating someone to do something. The bias of disliking regret describes the desire to avoid the feeling of remorse experienced after making a decision with negative outcome. Investors who are influenced by this bias take less risk, to reduce the potential of bad results. The bias may explain the investor's hesitation to sell the investments that have suffered losses, in order to avoid confronting the fact that they have taken bad decisions.

\section{Loss Aversion}

Loss aversion is a form of feeling of regret.This bias may encourage an investor to overestimate potential short-term losses and underestimate long-term returns and diversification profits.

Myopic loss aversion is a situation in which investors being extremely worried by the negative impact of losses compared to the positive impact of the same amount of profits, take a very short-term position towards investments. What is happening, is that investors pay more attention to short-term fluctuations in their investments. Although is not unusual for an average share to fluctuate a few percentages over a very short period of time, a myopic investor (or short-sighted) may not react in favor to negative changes. Therefore, it is believed that the shares must give a sufficiently high premium to recompense investor's great loss aversion.

\section{Mental Accounting}

A concept introduced for the first time by Richard Thaler (1999), mental accounting attempts to describe the process by which people code, categorize and evaluate economic outcomes. People may have multiple mental accounts for the same source. A person may use different monthly budgets for purchasing food and dining in restaurants, as well as limiting a purchase when his budget expires, without limiting another type of purchase, even though both purchases are applied from the same source.Mental Accounting is a term that describes our bias to categorize or group money into different "boxes" in our minds and then make decisions on how to use that money. It is our mental way to say, "This amount of money will be used for this purpose and this amount of money for another purpose" and this happens unconsciously. Mental Accounting can be useful. Maybe you have a stored account specifically for an emergency that you will not touch for any other reason. Or you can mentally determine a portion of your bank account that goes for your children's 
education. Sometimes it would be better that the money is split into different "boxes" for short, medium and long term purposes, so that you can invest in the right time.

Imagine a player who wins in a casino. The player, like the income-earning investor, did not have that money before, so he is more likely to play with the money "he earned" rather than the money he has saved. But the important thing is the total amount, not the origin of money. Another example of mental accounting is the greater willing to pay for goods when using credit cards than when using cash, and buying more goods when paying with a debit or credit card than in cash. Investors tend to think of their assets separately and not in total and cannot see interactions between different classes of assets (Thaler, 1985, 1999).They see income from real estateinvestments, investment in the stock market, or income from their job as separate investment decisions.

\section{Herding Effect}

Shiller (2005) claims that herding behavior plays a decisive role in the human decision-making process. Herding behavior is a source of price bad estimation and speculative bubbles (Shiller, 2005). Financial crises have occurred and are often repeated in financial markets. How is the repetition of these catastrophes possible? The answer to this is believed to be impacted by a human trait: behaving according to the "crowd", which is the bias for individuals to imitate actions (irrational or wrong) actions of a larger group. There are several reasons why this bias happens. The first is the social pressure of conformity. Most people have a natural desire to be accepted in a group, rather than being labeled as excluded, so following the group's behavior is an ideal way to become a member. The second reason is the collective reasoning that it is unlikely for such a large group to be wrong. Even though you are convinced that a particular action is irrational or inaccurate, you can still join the crowd, believing that they know something you do not know. This happens particularly when an individual is inexperienced.

The market and its participants are interdependent, which means that people's reactions affect market developments and vice versa. Investors as social beings seek to belong somewhere.

Besides the social part, they also get information from interactions with others. This is especially important in times of crisis and insecurity when someone perhaps inexperienced chooses to follow the others, using the principle "the others know better". This is an important bias when explaining market bubbles and crises.

The bias is usually not a very profitable investment strategy. This means that many investors who follow the "crowd" probably enter the game too late and are likely to lose money, while investors 'infront' of the bias start with new strategies.In the securities market, investors following this bias, base their investment decisions on the 'crowd' decisions to buy or sell shares. 
There are some elements that influence the behavior of an investor that shows this bias, such as: excessive self-confidence, type of investors, investment volume, etc. The more overconfident the investors are, the more they base on their own information to make investment decisions. On the er side individual investors tend to follow crowds when making investment decisions more than institutional investors (Goodfellow, Bohl \& Gebka, 2009, p. 213).

Waweru (2008, p. 37) identifies investment decisions on which the investor may be influenced by others: purchase, sale, choice of investment type, length of its retention and trading volume. In capital markets, the herding bias is followed daily. People with limited information follow those who think they have more information or better knowledge.The same thing happens with investors when they copy each other's portfolio. This behavior once again rejects the homo economicus proposition. In fixed income securities market, the media coverage of debt securities since the 2008 crisis has put the interest rate on investor's focus, intensifying their daily moves. In addition, the lack of independent opinion from many fixed-income institutional investors display the 'group thinking' phenomena (Paul \& Jonson, 2014).

\section{Other Psychological Bias}

\section{Confirmation Bias}

It is a psychological phenomenon that explains people's bias to seek that sort of information that confirms their existing thoughts and to ignore the sort of information that denies their beliefs. It affects our perceptions and our decision making process, hence we may take non-optimal choices. For example, many TV viewers prefer that television channel that represents their political views, avoiding those that display opinions of different thoughts. People do the same when it comes to financial issues.

Confirmation bias can create problems for investors. When an investor wants to make an investment, he may be inclined unconsciously to seek information that supports his belief concerning his investment andhe may not be able to see the information that presents different ideas. The result is a unilateral view of the situation which may cause that investors make poor decisions about the kind of investment they choose or the moment of buying or selling the asset. Confirmation bias serves as a selfconfidence source for investors. It helps explaining why the markets doesn't always function rationally. However, an investor who is aware of his confirmation bias, may be able to overcome it and seek contradictory advice. Confronting people of different thoughts from ours can help us we overcome confirmation biases and helps taking better decisions.

\section{Disposition Bias}

Investors tend to label investments as "winners" or "losers". The disposition bias may encourage an investor to holdan investment for too long that no longer provides any benefit. The bias consists in the bias of selling an asset that has increased in value and resist selling an asset that has fallen in value. 
The bias to sell "winners" to the "losers" is called the Disposition Bias. If investor would focus on his wealth rather than his emotions, he would sell the "losers" and hold the "winners". Besides, one of the documented abnormalities in the financial markets is that the shares increasing its value recently, will continue to increase its value at least for a short time ahead. It is understood that experienced investors who are more 'vigilent' fall less for this bias than the inexperienced one or beginners.

\section{Retrospective Bias}

A bias that tends to happen in a situation after an event has occurred, the person believes that the occurrence of that event was predictable and obvious, while in reality the event could not have been rationally predicted. Finding the wrong connection between the cause and effect of an event, may result in incorrect excessive simplification. Financial bubbles are often the subject of this bias. After almost every financial bubble, experts and analysts tried to show that how a past event, unimportant at the time, was actually a warning to future financial problems, the signs were very obvious. This is a clear example of retrospective prejudices: If the bubbles' signals were clear at that time, it might not have been escalated and eventually exploded. The illusion that we understand the past, stimulates the confidence in our ability to predict the future (Thinking Fast and Slow, pg. 218).

\section{Familiarity and Home Bias}

It happens when investors prefer to invest in known assets for them. If you have to choose to invest in one of the 2 investment funds: the one you have heard sth. about and the other not. Which of them would you choose? If we surrender to the familiarity bias, we would choose the fund that we have heard somewhere. Familiarity and security are two different things. Familiarity can contribute to a lack of diversification, thus increasing the risk. If people know a certain section because they work for it every day, they feel they know very well this section, thus they can decide to distribute a large part of their investments in the section. The risk is that if the section has a crisis, they are exposed to double risk (employment and investment).

The influence of familiarity on investments choice, relates also to the country where investors live (the bias to invest in local assets - home bias). Some investors tend to buy shares from companies in their country instead of risk-sharing through investment in different countries. Just as a potential risk rises of excessive investment in a particular section, it can also extended from excessive investment in a certain country.

\section{Self-attribution Bias}

Investors who suffer from self-attribution bias, tend to attribute the successful results to their personal ability and the bad results to 'bad-luck' (Shepherd, pp. 101, 1999). They often manifest this bias as self-defensive. Investors affected by the selfattribution bias can gain excessive self-confidence. When their portfolio grows, they 
take the credit, but when they lose, they blame immediately external factors outside of their control, for example: market forces.

Although this tends to make you feel better, you simply fooling yourself, instead of taking advantage of thiscase to improve your investment intelligence. The higher the return to the previous period, the more investors confirm that the recent performance reflects their investment capabilities and vice versa (ArvidO.I.Hoffmann and Thomas Post 19 ...).

\section{Optimism Bias}

It's the bias to believe that the future will be better than the past and the present. Hoping to help you achieve your goals and cope with the obstacles. Various researches shows that people are more optimistic than realistic.When people predict the future, they overrate the chances of positive events and underestimate the chances of negative events. In a world full of insecurities and competition, being positive without disconnecting from reality, is useful. Nobel Prize winner Daniel Kahneman writes in his book Thinking Fast and Slow, that optimistic individuals play an important role in our lives.They are often inventors, entrepreneurs, leaders who have reached where they are, seeking for challenges and risks. On the other hand, unrealistic expectations for the future may result in impulsive behavior, as borrowing more than what people can afford, negligence on insurance, etc.

To manage this bias, it is recommended to perform a pre-mortem (Gary Klein, 2007). A pre-mortem is the hypothetical opposite of a post-mortem. The idea is simple: before taking a risky decision (such as starting a business or investing in shares), imagine that the it was taken months ago and resulted in a dramatic failure. Now think about all possible reasons of this failure. This method forces people to act against their own confirmation bias, the natural bias to seek only evidences that support an original belief. Pre-mortem will reduce the post-mortem pain that hits when the reality does not match the optimistic expectations.

Optimism bias is considered to be one of the most important psychological biases of all.

\section{Planning Fallacy}

This bias is a phenomenon that was first proposed by Daniel Kahneman and Amos Tversky in 1979, according to which the prediction of the necessary time to complete a task in the future, shows the bias of optimism and underestimates the necessary time. It describes the bias for people to overestimate their work pace or to underestimate the time they need to complete things. It is a stronger bias for long and complicated tasks and disappears or fades for simple tasks that are easier to complete (Buehler, Roger, Griffin, Dale, Ross, Michael, 1994).

This bias only affects the expectations for its tasks. When external observers predict the timing of a task, they exhibit a pessimistic bias overestimating the necessary time. 
An extended definition includes the bias to underestimate future actions concerning time, costs and risk as well as overestimate the benefits of the same actions (Lovallo and Kahneman 2003).

The phenomenon can be explained by the concept of 'wishful thought' by which people feel that tasks will end quickly and easily because that's what they want to (Roger Buehler 19.).Some real examples illustrating this bias:

1. The Sydney Opera Theater was expected to be completed in 1963 at an estimated cost of $\$ 7$ million. A diminished version of it opened a decade later at a cost of 102 million dollars.

\section{Endowment Effect}

It happens when we overestimate the goods we possess, regardless of its objective market value (Kahneman, Knetsch, \&Thaler, 1991). Studies have repeatedly shown that people will estimate something they already have, more than just a similar item they don't have, especially true of goods that are normally not bought or sold on the market, usually items of symbolic or emotional importance. According to an old saying: "It is better to have a bird on your hand, than two in the tree".

The impact is an illustration of the bias of the status quo (the preference to not change the situation in which you are which is taken as a reference point and any change from which is perceived as a loss) and can be explained by loss aversion. According to this effect, investors are inclined to hold on certain assets due to familiarity and comfort, even if they are inappropriate or become useless. The endowment effect is an example of an emotional bias.

\section{Literature summary on empirical findings about psychological biases}

The following is a summary of the literature of studies on psychological factors influencing the investor's behavior:

\begin{tabular}{|c|c|c|}
\hline Bias & Author & Findings \\
\hline \multirow[t]{2}{*}{ Availability } & $\begin{array}{l}\text { Tversky and } \\
\text { Kahneman (1973, } \\
\text { 1974) }\end{array}$ & $\begin{array}{l}\text { The facility certain cases come to } \\
\text { mind. It creates a selective bias in } \\
\text { decision-making. }\end{array}$ \\
\hline & $\begin{array}{l}\text { Kliger and } \\
\text { Kudryavtsev } \\
(2010)\end{array}$ & $\begin{array}{l}\text { Price feedback is stronger when is } \\
\text { associated with the same course of } \\
\text { index return. }\end{array}$ \\
\hline \multirow[t]{2}{*}{ Anchoring } & $\begin{array}{l}\text { Tversky and } \\
\text { Kahneman (1974) }\end{array}$ & $\begin{array}{l}\text { People's bias to estimate unknown } \\
\text { quantities with the help of an initial } \\
\text { "anchor" value. }\end{array}$ \\
\hline & $\begin{array}{l}\text { Campbell and } \\
\text { Sharpe (2009) }\end{array}$ & $\begin{array}{l}\text { Expert forecasts are biased } \\
\text { (anchored) to the results of } \\
\text { previous months }\end{array}$ \\
\hline
\end{tabular}




\begin{tabular}{|c|c|c|}
\hline \multirow[t]{4}{*}{ Overconfidence } & Odean (1998) & $\begin{array}{l}\text { Investors' bias to overestimate the } \\
\text { precision of their knowledge of the } \\
\text { value of securities }\end{array}$ \\
\hline & $\begin{array}{l}\text { Daniel, Hirshleifer } \\
\text { and } \\
\text { Subrahmanyam } \\
(1998)\end{array}$ & $\begin{array}{l}\text { Investors' overconfidence leads to a } \\
\text { negative serial correlation in prices. }\end{array}$ \\
\hline & $\begin{array}{l}\text { Barber and Odean } \\
(2000)\end{array}$ & $\begin{array}{l}\text { Overconfidence leads investors to } \\
\text { excessive trading, which reduces } \\
\text { their wealth due to higher trading } \\
\text { costs. }\end{array}$ \\
\hline & $\begin{array}{l}\text { Gervais and Odean } \\
(2001)\end{array}$ & $\begin{array}{l}\text { Past successes enhance investor's } \\
\text { self-confidence and increase future } \\
\text { trading volume. }\end{array}$ \\
\hline \multirow[t]{4}{*}{$\begin{array}{l}\text { Optimism } \\
\text { (Pessimism) }\end{array}$} & $\begin{array}{l}\text { Heifetz and Spiegel } \\
(2001)\end{array}$ & $\begin{array}{l}\text { The investor's bias to } \\
\text { over/underestimate the expected } \\
\text { average return of risk asset. }\end{array}$ \\
\hline & $\begin{array}{l}\text { Toshino and Suto } \\
\text { (2004) }\end{array}$ & $\begin{array}{l}\text { Optimistic investors select only the } \\
\text { good news in their decision-making } \\
\text { process. }\end{array}$ \\
\hline & $\begin{array}{l}\text { Shefrin and } \\
\text { Statman (2011) }\end{array}$ & $\begin{array}{l}\text { Excessive optimism creates } \\
\text { speculative bubbles in financial } \\
\text { markets. }\end{array}$ \\
\hline & $\begin{array}{l}\text { Hoffman and Post } \\
\text { (2011) }\end{array}$ & $\begin{array}{l}\text { Identifying the optimism and } \\
\text { pessimism (expected return, } \\
\text { tolerance and risk perception). }\end{array}$ \\
\hline \multirow[t]{4}{*}{ Loss aversion } & $\begin{array}{l}\text { Kahneman and } \\
\text { Tversky (1979) }\end{array}$ & $\begin{array}{l}\text { Loss leads to regret and people try } \\
\text { to avoid losses so that they don't } \\
\text { feel bad afterwards. }\end{array}$ \\
\hline & $\begin{array}{l}\text { Coval and } \\
\text { Shumway (2003) }\end{array}$ & $\begin{array}{l}\text { Studied loss aversion in intraday } \\
\text { trading. A loss in the morning leads } \\
\text { to taking higher risk in the } \\
\text { afternoon. }\end{array}$ \\
\hline & $\begin{array}{l}\text { Berkelaar and } \\
\text { Kouwenberg } \\
(2008)\end{array}$ & $\begin{array}{l}\text { Investors become less risk averse } \\
\text { when they experience profits, } \\
\text { increasing securities' price. }\end{array}$ \\
\hline & $\begin{array}{l}\text { Hwang and Satchell } \\
(2010\end{array}$ & $\begin{array}{l}\text { The level of loss aversion depends } \\
\text { on the market terms, being higher }\end{array}$ \\
\hline
\end{tabular}




\begin{tabular}{|c|c|c|}
\hline & & $\begin{array}{l}\text { in the 'bull'1 market than in the } \\
\text { "bear'2 market. }\end{array}$ \\
\hline \multirow[t]{2}{*}{ Representativeness } & $\begin{array}{l}\text { Tversky and } \\
\text { Kahneman (1974) }\end{array}$ & $\begin{array}{l}\text { Individuals' bias to estimate the } \\
\text { probability of an event to occur, } \\
\text { comparing it with an earlier } \\
\text { incident that already exists in their } \\
\text { minds. }\end{array}$ \\
\hline & Kumar (2001) & $\begin{array}{l}\text { The past price bias is } \\
\text { representative of the future price } \\
\text { bias as investors tend to buy shares } \\
\text { with positive above-average } \\
\text { returns. }\end{array}$ \\
\hline \multirow[t]{2}{*}{ Mental accounting } & Thaler (1999) & $\begin{array}{l}\text { Investors preserve mental accounts } \\
\text { of their property, which affects the } \\
\text { decisions on stock selection. }\end{array}$ \\
\hline & $\begin{array}{l}\text { Barberis and Huang } \\
(2001)\end{array}$ & $\begin{array}{l}\text { Changes in the investor's mental } \\
\text { accounting system affect asset } \\
\text { prices. }\end{array}$ \\
\hline \multirow[t]{3}{*}{ Endowment effect } & $\begin{array}{l}\text { Shefrin and } \\
\text { Statman (1985) }\end{array}$ & $\begin{array}{l}\text { Investors' disposition to sell } \\
\text { winners too early and hold on } \\
\text { losers for too long. }\end{array}$ \\
\hline & $\begin{array}{l}\text { Grinblatt and } \\
\text { Keloharju (2001) }\end{array}$ & $\begin{array}{l}\text { Evidence of endowment effect on } \\
\text { Finnish stock market. }\end{array}$ \\
\hline & Alok Kumar (2009) & $\begin{array}{l}\text { To avoid regret, investors hold } \\
\text { 'losers' shares hoping there will get } \\
\text { future profits. }\end{array}$ \\
\hline \multirow[t]{2}{*}{ Herding } & $\begin{array}{l}\text { Scharfstein and } \\
\text { Stein (1990) }\end{array}$ & $\begin{array}{l}\text { Examined this bias on managers. } \\
\text { The reputation and the effect of } \\
\text { "sharing the guilty" lead to join } \\
\text { herding behavior. }\end{array}$ \\
\hline & $\begin{array}{l}\text { Christie and Huang } \\
\text { (1995) }\end{array}$ & $\begin{array}{l}\text { Examined the bias using the } \\
\text { standard cross-sectional deviation. } \\
\text { They analyzed the presence of this } \\
\text { bias in market's extreme periods. }\end{array}$ \\
\hline
\end{tabular}

Table 1.5: Literature summary of the main psychological bias

\footnotetext{
${ }^{1}$ The financial market of a group of securities in which prices are rising or are expected to grow. The term is most often used to refer to the stock market, but it can be applied to everything that is traded, such as bonds, currencies, and commodities. Bull markets are characterized by optimism, investor confidence, and expectations that the trend should continue.

2 The opposite of the bull market; is characterized by price declines and pessimism. Using the terms "bulls" and "bear" to describe markets comes from how animals attack their opponents. Bulls keeps horns up in the air, whereas the bear slams the paws on the ground. These actions are metaphors for market movement. If the trend is up, it's a bull market, if it's down, it's a bear market.
} 
Source: Prosad, Kapoor, Sengupta, 2015

\section{Conclusion}

The way investors think and feel, affects the way they behave when making investment decisions. These impacts are known as psychological biases. They affect all investors and vary depending on the type of investor. Based on theories developed in the field of financial behavior, heuristics is that approach which uses short mental methods, fast, efficient rules, in order to reduce mental efforts during decisionmaking process. While it can lead to right decisions, it can also lead to wrong decisions as a result of errors in judgment or psychological deviations. Such tendencies included in heuristics are: Representativeness, Availability, Anchoring, Gambler's Fallacy, Overconfidence. Another theory developed by Behavioral Finance is Perspective Theory, which has a high level of explanatory power about individual behavior during decision-making. Psychological biases which are included in this theory are: Loss aversion, Regret aversion, Mental Accounting. Other behavioral biases are consequently listed in the paper, each of them being quite important in individual financial behavior. Markets reflect the collective independent decisions of millions of people and when market forces unify with human ones, it can result in financial crisis, which have actually happened throughout human history. That's why all of us have to by wary of learning how to deal with situations which require logic, processing and analysis of information and because of our limitations in time, sources, and knowledge we are prone to our psychology. In such cases we should know ourselves better, know our vulnerability to behavioral biases and try to reduce the errorness of our actions.

\section{References}

[1] Amos Tversky and Daniel Kahneman (1974) "Judgment under Uncertainty: Heuristics and Biases"Science, New Series, Vol. 185, No. 4157. (Sep. 27, 1974), pp. 1124-1131. Available at: http://psiexp.ss.uci.edu/research/teaching/Tversky_Kahneman_1974.pdf

[2] Amos Tversky and Daniel Kahneman (1974) "Judgment under Uncertainty: Heuristics and Biases”Science, New Series, Vol. 185, No. 4157. (Sep. 27, 1974), pp. 1124-1131. Available at:

http://psiexp.ss.uci.edu/research/teaching/Tversky_Kahneman_1974.pdf

[3] Barber and Odean, 2000, The Behavior of Individual Investors, https://faculty.haas.berkeley.edu/odean/papers\%20current\%20versions/b ehavior\%20of\%20individual\%20investors.pdf

[4] Bloomfield, Libby and Nelson, Confidence and the welfare of less-informed investors, Accounting, Organizations and Society, 1999, vol. 24, issue 8, 623647, https://econpapers.repec.org/article/eeeaosoci/v_3a24_3ay_3a1999_3ai_3a 8_3ap_3a623-647.htm 
[5] Camerer and Lovallo, Overconfidence and Excess Entry: An Experimental Approach, February 1999, American Economic Review 89(1):306-318, https://www.researchgate.net/publication/4980840_Overconfidence_and_E xcess_Entry_An_Experimental_Approach

[6] DANIEL KAHNEMAN AND AMOS TVERSKY (1972), COGNITIVE PSYCHOLOGY 3, 430454 (1972) Subjective Probability: A Judgment of Representativeness. http://datacolada.org/wpcontent/uploads/2014/08/Kahneman-Tversky-1972.pdf

[7] Durand, Newby and Sanghani (2008) "An intimate portrait of the individual investor". Journal of Behavioral Finance Volume 9, 2008 - Issue 4. Available at: https://www.tandfonline.com/doi/abs/10.1080/15427560802341020

[8] Frank R. Kardes, Steven S. Posavac and Maria L. Cronley (2004) "Consumer Inference: A Review of Processes, Bases, and Judgment Contexts". JOURNAL OF CONSUMER PSYCHOLOGY, 14, 2004. Available at:

http://citeseerx.ist.psu.edu/viewdoc/download?doi=10.1.1.458.4254\&rep= rep1\&type $=$ pdf

[9] Grabova 2013, "Ndikimi i kultures dhe emocioneve ne sjelljen dhe vendimmarrjen e individit" http://www.doktoratura.unitir.edu.al/wpcontent/uploads/2013/12/Doktoratura-Perseta-Grabova-FakultetiEkonomik-Departamenti-i-Finances.pdf

[10] H. Kent Baker and Victor Ricciardi (2014) "How Biases Affect Investor Behavior". The European Financial Review February - March 2014. Available at: http://www.smallake.kr/wp-content/uploads/2016/07/SSRNid2457425.pdf

[11] JamesMontier (2006) "Behaving Badly".Global Investment Strategy Research Analysts2 February 2006. Available at:

http://www.kellogg.northwestern.edu/faculty/ Kahneman, 2011/decs452/behaving_badly.pdf

[12] Mark Grinblatt and Matti Kelohajru (2001) "What Makes Investors Trade". The Journal of Finance Vol. LVI, No. 2 • April 2001. Available at:

file://C:/Users/Administrator/Downloads/what_makes_investors_trade.pd $\mathrm{f}$

[13] Mental accounting matters Richard H. Thaler Journal of Behavioral Decision Making; Sep 1999; 12, 3; ABI/INFORM Global pg. 183 https://elearning2.uniroma1.it/pluginfile.php/101759/mod_resource/cont ent/1/Thaler1999.pdf

[14] Michael M. Pompian, Behavioral Finance and Wealth Management: ISBN: 978-1-118-18229-1. Nov 2011, https://www.wiley.com

[15] Odean 1998, Are Investors Reluctant to Realize Their Losses? Research Gate. https://papers.ssrn.com/sol3/papers.cfm?abstract_id=94142

[16] ORGANIZATIONAL BEHAVIOR AND HUMAN DECISION PROCESSES 39, 8497 (1987) Experts, Amateurs, and Real Estate: An Anchoring-andAdjustment Perspective on Property Pricing Decisions GREGORY B. 


\section{NORTHCFCAFTANDMARGARET A. NEALE}

http://web.missouri.edu/segerti/capstone/northcraft_neale.pdf

[17] Simonsohn U., Karlsson N., Loewenstein G., Ariely D. The tree of experience in the forest of information: Overweighing experienced relative to observed information. Games and Economic Behavior. 2008;62(1):263-286.

[18] Slovic P \& Lichtensteln S. Comparison of Bayesian and regression approaches to the study of information processing in judgment. Organ. Behav. Hum. Perform. 6:649- 744, 1971. [Oregon Research Institute, OR] http://garfield.library.upenn.edu/classics1980/A1980JX53800001.pdf

[19] Venter and Michayluk (2007) "A Longitudinal Study of Financial Risk Tolerance", http://citeseerx.ist.psu.edu/viewdoc/download?doi=10.1.1.533.166\&rep=re p1\&type $=$ pdf

[20] Waweru, N., M., Munyoki, E., \& Uliana, E. (2008). “The effects of behavioral factors in investment decision-making: A survey of institutional investors operating at the Nairobi Stock Exchange-International Journal of Business and Emerging Markets". Int. J. Accounting, Auditing and Performance Evaluation, Vol. 7, No. 4, 2011.Available at: file://C:/Users/Administrator/Downloads/IJAAPE070404Published2011.p df

[21] Werner F. M. De Bondt and Richard Thaler (1985) "Does the Stock Market Overreact?" The Journal of Finance, Vol. 40, No. 3, Papers and Proceedings of the Forty-Third Annual Meeting American Finance Association, Dallas, Texas, December 28-30, 1984. (Jul., 1985), pp. 793-805. Available at: http://breesefine7110.tulane.edu/wpcontent/uploads/sites/110/2015/10/Debondt-and-Thaler.pdf

[22] Zweig 2011, "Know your clients", https://zweiggroup.com/2011/01/03/know-your-clients/ 